\title{
KATE STITH
}

\section{THE HEGEMONY OF THE SENTENCING COMMISSION}

\author{
Kate Stith*
}

Some observers have expressed the hope that the Supreme Court's decision in Koon v. United States ${ }^{1}$ may permit both sentencing judges and appellate courts to consider fundamental issues of culpability and just punishment in deciding whether there should be a departure from the guidelines. In Koon, the Court unanimously embraced the notion that the sentencing guidelines deal with "heartland" cases, and that judges may depart in cases outside the "heartland." The concept of "heartland" had appeared only in a single sentence in the introductory chapter of the guidelines when they were issued in 1987,2 but in 1994 a reconstituted Commission added a new paragraph expressly recognizing the concept in the chapter of the guidelines governing departures. ${ }^{3}$

Potentially more significant than its embrace of the "heartland" concept, Koon held that departures should be reviewed by appellate courts under an "abuse of discretion" standard. 4 A cursory reading of the Court's decision may reinforce the media's misimpressions of the decision-that the Supreme Court has mollified district judges by giving them more discretion and mollified circuit judges by relieving them of much of the burden of guidelines appeals..$^{5}$ Koon does contain language that suggests sentencing courts will be given significant deference in deciding to depart; it says, for instance, "the district court retains much of its traditional discretion," and "[a] district court's decision to depart from the Guidelines . . . will in most cases be due substantial deference." 6

Yet despite Koon's expansive dicta regarding the scope of sentencing court discretion, federal appellate courts have not generally recognized the decision as granting sentencing judges greater departure authority than had existed.' In Koon's wake, many circuits have continued to subject departures to significant scrutiny. ${ }^{8}$ The truth is that Koon is a puzzling decision; its proclamations about the extent of deference due sentencing judges ${ }^{9}$ are difficult to reconcile with the reasoning and holdings stated elsewhere in the decision.

Even with these ambiguities, a thorough and candid assessment of Koon requires the conclusion that it has not changed matters significantly, and perhaps not at all. Neither the "heartland" concept nor Koon's articulation of an abuse-of-discretion standard provides the hoped-for relaxation of the guideline regime. In particular, Koon leaves intact the

* Professor of Law, Yale Law School; member, FSR Advisory Board. major obstacle to more meaningful judicial participation in criminal sentencing: the provision of the Sentencing Reform Act that permits departure only on grounds not "adequately" considered by the Commission. ${ }^{10}$ The Supreme Court in Koon followed the lead of the federal courts of appeal prior to Koon in treating consideration by the Commission as, ipso facto, "adequate" consideration." Because no secondguessing of the Commission is permitted, sentencing judges and appellate courts are denied authority to consider the arbitrariness of the guidelines themselves. In the words of one recent appellate court decision, Koon does nothing to alter the rule that "[a] sentencing court may not depart from an otherwise applicable guideline range simply because its own sense of justice would call for it." ${ }^{12}$ Put another way, the question whether the applicable guidelines produce justice in the case at hand is not open for consideration either by sentencing courts or appellate courts.

In the wake of Koon, as before Koon, the main question on appeal of a departure continues to be whether the Sentencing Commission has already taken into account the factors that the sentencing judge has identified as warranting departure in the present case. ${ }^{13}$ And this question-whether the Sentencing Commission has already considered these factors-is not subject to a meaningful abuse-ofdiscretion standard. To be sure, at one point Koon states that district courts have "an institutional advantage over appellate courts" in deciding questions such as " $[w]$ hether a given factor is present to a degree not adequately considered by the Commission, or whether a discouraged factor nonetheless justifies departure because it is present in some unusual or exceptional way ..." ${ }^{14}$ Yet, as explained below, in unpacking this multiple inquiry, Koon gave deference to the sentencing court only on the question of which factors are present in the case at hand, not on the question whether the Commission had already taken that factor adequately into account-that is, not on the question of what constitutes the "heartland" case. Indeed, Koon explicitly reaffirmed the rule that reviewing courts should consider de novo (that is, without deference) the "legal conclusions" that a district court makes in asserting departure authority, and noted that "[a] district court by definition abuses its discretion when it makes an error of law."15 Koon makes clear that only if the circumstances identified by the district judge take the case out of the "heartland" (that is, if the circumstances have not been already factored into the guidelines) must the reviewing court accord deference to the sentencing court's decision to depart on these grounds. ${ }^{16}$

In point of fact, the Sentencing Commission has already factored in most circumstances that are arguably relevant to criminal sentencing. It has done so by prohibiting altogether consideration of some factors, and by specifying the weight to be accorded 
other significant factors depending on the degree to which they are present. (Among the prominent factors thus considered by the Commission are the presence or absence of a criminal record, the defendant's role in the offense, the quantity of harm, and whether the defendant has accepted responsibility for the crime.) That is, the guidelines are, as Congress intended them to be, comprehensive. ${ }^{17}$ Koon makes it clear that the judge may not depart because he disagrees with these comprehensive and thorough sentencing instructions. That is, the judge may not depart because he disagrees with the weight the guidelines give to a circumstance in the typical case, or because he disagrees with the Commission's prohibition of consideration of certain factors. Moreover, with respect to commonly occurring circumstances that are not explicitly addressed by the guidelines, Koon teaches that the benefit of the doubt must be given to the Commission-that is, it must be assumed that the Commission has already taken the matter into account. ${ }^{18}$ Deference to the sentencing court is due only on the question whether factors clearly not taken into consideration or factors that are atypically present (that is, factors that take the case out of the "heartland") warrant departure.

The limited significance of Koon's abuse-ofdiscretion standard is amply demonstrated in Koon itself. The defendants in that notorious case-former policemen who had previously been acquitted in a state trial for the beating of Rodney King-had been convicted in federal court of criminal violations of King's civil rights. ${ }^{19}$ Each had a calculated Guideline Offense Level of 27. The sentencing judge departed five levels downward on a ground specifically identified by the guidelines as possibly warranting departure - that the victim had partially provoked the assault. ${ }^{20}$ The sentencing judge then cited four other circumstances that he thought were atypical in the case and together warranted an additional downward departure of three levels: (1) the heightened likelihood that these defendants would be targets of prison abuse, (2) the fact that the defendants would forever after be disqualified from jobs in law enforcement, (3) the fact that these defendants were especially unlikely to be recidivists, and (4) the fact that the defendants had been burdened by successive state and federal prosecutions. ${ }^{21}$ The Court of Appeals for the Ninth Circuit reversed, rejecting the appropriateness of any of these downward departures. ${ }^{22}$ The Supreme Court in turn reversed the appeals court, embracing the "heartland" theory of the guidelines and seeming to adopt a deferential abuse-of-discretion standard for review of departures.

Yet the Supreme Court's actual application of these abstract concepts belies the notion that the Court has enhanced the discretion of sentencing judges. Every Justice agreed with the appeals court in Koon that the sentencing judge had erred in considering the defendant's extremely low likelihood of recidivism as a basis for departure-because, the Justices asserted, this consideration must have already been taken into account by the Commission in defining Criminal History Category I (limited to those with no criminal record or a very minor record). ${ }^{23}$ In explaining its refusal to uphold the sentencing judge on this issue, moreover, the Supreme Court did not even mention the "heartland" concept it had just enunciated, nor suggest that any deference was due the trial court on this question. Nor did the Court even comment on whether the Commission's consideration of low risk of recividism was "adequate" - which is, after all, the statutory standard for deciding whether the sentencing court is authorized to depart. ${ }^{24}$ The only fair reading of Koon on this point is that there is no room for a sentencing court to decide that Criminal History Category I "inadequately" takes low risk of recividism into account. The Commission has effectively prohibited departures on this basis, ${ }^{25}$ comparable to its direct proscription of departure on certain other grounds. ${ }^{26}$ As to any matter that the Commission has prohibited as a basis for departure, the Commission's consideration of the matter is, ipso facto, adequate.

Similarly, eight Justices in Koon thought it was improper for the sentencing court to consider the defendants' career loss. This portion of the opinion began by explaining that officials convicted of civil rights offenses almost always will be barred from future government employment. Accordingly, this factor is not "unusual" and "cannot take the case out of the heartland" of the guidelines for civil rights violations. ${ }^{27}$ Moreover, because this factor lay within the "heartland," the Commission presumably considered it, and, ipso facto, the Commission had adequately considered it. (In the Court's words: "It is to be expected that a government official would [suffer career loss for civil rights violations], so we conclude that these consequences were adequately considered by the Commission in formulating [the civil rights violation guideline]." ${ }^{28}$ ) Under Koon, neither sentencing courts nor appellate courts-including even the Supreme Court-may secondguess the "adequacy" of the Commission's treatment of anything that presumably lies in the "heartland."

Six of the Justices concluded that the sentencing court "did not abuse its discretion" in relying on two other factors: the defendants' susceptibility to abuse in prison, and the burden of a long state prosecution before the federal prosecution. The sentencing guidelines do not explicitly address either of these circumstances. In deferring to the sentencing judge's assessment that susceptibility to prison abuse (along with other grounds) warranted departure, the majority expressly noted that judge had relied on the "extraordinary notoriety" of the case and had found that the defendants would be "particularly" susceptible to abuse in prison. ${ }^{29}$ As to the legality of departing on the ground of successive prosecutions, 
the majority expressed its own view that the state trial had been "lengthy." 30 (The District Court in fact had made no finding that this was an atypical sucessive prosecution; rather, for the sentencing judge, the mere fact of a federal prosecution after a state acquittal made the case unusual. ${ }^{31}$ ) Again, it appears that the majority did not defer at all to the sentencing judge on the question of what constitutes the "heartland" case; nor is it even clear that the majority deferred to the District Court on the question whether particular factors are atypically present in the case at hand. The majority did clearly defer on the question whether atypically-present factors warrant departure in the case, and, significantly, on the extent of departure warranted.

The partial dissents in Koon are also instructive. Justices Ginsburg and Breyer agreed with Justice Souter's dissenting view that susceptibility to mistreatment in prison should never be a basis for departure where the susceptibility stems from the egregious nature of the crime itself; 32 that is, these justices disputed the legal conclusion that such susceptibility takes the case outside the "heartland." Like their colleagues, the dissenters on this question did not suggest that the sentencing judge was owed any deference on what constitutes the "heartland."

These three Justices also disagreed with the majority that the burden of successive prosecutions warranted departure. Justice Breyer's opinion is most instructive in this regard, for as a member of the Sentencing Commission when it promulgated the civil rights guidelines, he presumably knew what "heartland" case the Commission had in mind. Justice Breyer believed that the Commission considered a double prosecution "ordinarily within, not outside, the 'civil rights' Guidelines's 'heartland.'"33 After all, he explained, federal criminal civil rights statutes exist to permit prosecution "where state law enforcement efforts had proved inadequate." 34

But the Sentencing Reform Act makes a former Commissioner's knowledge (and anybody else's) irrelevant. Shortly after the sentencing guidelines went into effect, the departure provision was amended to provide that in determining whether a circumstance was "adequately" taken into consideration by the Commission, courts may "consider only the sentencing guidelines, policy statements, and official commentary of the Sentencing Commission." 35 It thus appears that whatever Justice Breyer may have known about the Commission's thinking when it wrote the civil rights violation guideline was not sufficiently apparent in the guideline itself to persuade a majority of his colleagues. After Koon, as before, the fundamental question whether the Commission has taken a particular circumstance into account is not only a legal question on which no deference is due the trial judge, it is also a question that must be addressed in a highly abstract and speculative way. The real question is not whether the
Commission actually took some factor into account, but rather, whether the factor is rare enough to overcome the presumption that the Commission took it into account.

In sum, the Supreme Court in the Koon case unanimously embraced the "heartland" concept and adopted a deferential standard of review, but the Court was also unanimous in concluding that the reviewing court should not apply a deferential standard to the basic issue that arises in every departure case: whether the Commission has already taken into account a particular circumstance or factor that the sentencing judge relied on in departing (or, stated another way, what factors are present, and to what degree, in the "heartland" case). Koon makes clear that courts must presume that the Commission has already taken into account all unmentioned circumstances that occur typically in the commission of crimes for which guidelines have been promulgated. Koon thus leaves sentencing courts approximately where they were: with departure authority only in cases that are "atypical" in ways neither proscribed from consideration by the Sentencing Commission nor already considered by the Commission. Koon also leaves appellate courts approximately where they were: with responsibility to police departures, prohibiting departures based on anything other than the "atypicality" of the case at hand. There is no room to question the reasonableness of the Commission's judgments about just punishment in the "typical" (or "heartland") case, and no room to question any determination the Commission has made regarding the proper (and improper) grounds for departure from the guidelines ranges. ${ }^{36}$

It is too bad that Koon did not do more. Koon would have permitted meaningful exercise of discretion by district courts-as it claimed to have done-if it had combined its abuse-of-discretion standard with a willingness to let sentencing judges evaluate, on a case-by-case basis, the adequacy of the guidelines' specification of relevant sentencing factors and the various weights the guidelines accord to these factors. Under one approach, for instance, the task of the sentencing judge would be to determine whether the Commission's consideration of sentencing factors is adequate in the case at hand. If the sentencing court answers that question in the negative, it would have to identify the factors it deems relevant and explain why they warrant a sentence outside the guideline range prescribed for this case. The task of the appellate court, when faced with such a departure from the guideline range, would be, in the words of the Sentencing Reform Act itself, to decide whether the departure is "reasonable." 37 In making this decision, the appellate court would perforce review, on an abuse-of-discretion standard, the sentencing judge's determination that the guidelines' identification and weighing of relevant sentencing factors is inadequate in the case at hand. There would be no 
irrebuttable presumption that consideration of a factor by the Commission is, ipso facto, adequate consideration (in the "typical" case or otherwise) ${ }^{38}$ —though courts might well conclude over time that the Commission's consideration of sentencing factors is adequate and reasonable in most cases.

For the Supreme Court to have adopted such a meaningful abuse-of-discretion standard for departures, permitting both trial judges and appellate courts to assess the work of the Sentencing Commission, would have been a radical departure from the theory underlying the federal sentencing guidelines as we know them. The Court would have given judges a role in determining a just punishment not only in the rare or atypical case, but in all cases. It would have encouraged the Commission not only to promulgate sentencing rules and weights, but also to explain the reasoning behind these prohibitions and prescriptions.

The language of the Sentencing Reform Actauthorizing departure if the sentencing court finds in the case at hand "an aggravating or mitigating circumstance of a kind, or to a degree, not adequately taken into consideration by the Sentencing Commission in formulating the guidelines that should result in a sentence different from that [prescribed by the Guidelines] $]^{\prime 39}$ - actually permits and arguably invites the approach suggested here. All that would be needed is a Supreme Court willing to question the hegemony of the Sentencing Commission.

\section{NOTES}

1116 S. Ct. 2035 (1996).

${ }^{2} \S 1 \mathrm{~A} 4$ (b) ("The Commission intends the sentencing courts to treat each guideline as carving out a 'heartland,' a set of typical cases embodying the conduct that each guideline describes. When a court finds an atypical case ..., the court may consider whether a departure is warranted.").

${ }^{3}$ The new sentence in $\S 5 \mathrm{~K} 2.0$ provides: "An offender characteristic or other circumstance that is not ordinarily relevant ... may be relevant to [a departure] determination if such characteristic or circumstance is present to an unusual degree and distinguishes the case from the 'heartland' cases covered by the Guidelines. ..." In accompanying Commentary, the Commission said that it "believes that such cases [justifying departure on the basis of 'ordinarily' not relevant characteristics] will be rare."

${ }^{4}$ See 116 S. Ct. at 2048.

${ }^{5}$ See, e.g., BNA Criminal Practice Manual, Koon Decision: Mere Lip Service to Sentencing Discretion? 10: 289 (1996).

${ }^{6} 116$ S. Ct. at 2046.

${ }^{7}$ Judge Richard Posner has noted that Koon did not mention, in its recitation of the statutory requirements for departure, the requirement that departure be "consistent" with the broad goals of criminal punishment listed in 18 U.S.C. $\$ 3553(a)(2)$. See United States v. Pullen, 89 F.3d 368,
370 (7th Cir. 1996). Whether this lack of citation by the Supreme Court is properly characterized as "reject[ing] this limitation on sentencing discretion," as Judge Posner asserts, id., or whether Koon only inadvertently failed to quote this language, will have to await further clarification. In any event, it would be strange (to say the least) for the Supreme Court to purport to authorize judges to to depart in ways that defeat the statutory purposes of sentencing. It also may be noted that Judge Posner does not appear to read Koon as increasing departure authority in any other way. See id. at 371-72.

Cases that arguably do read Koon as increasing discretion to depart include United States $v$. Beasley, 90 F.3d 400 (9th Cir. 1996) (concluding that Koon had overruled circuit law that required two-part departure inquiry-legal questions under de novo standard of review, and factual questions under "clear error" standard; then conducting inquiry consistent with circuit's previous standards); United States v. Joost, 92 F.3d 5, 7 (1st Cir. 1996) (upholding upward departure on basis specifically identified by Commission as warranting upward departure; but also citing deference language of Koon). See also United States $v$. Weise, 89 F.3d 502, 507 (8th Cir. 1996) (Gibson, J., concurring in part and dissenting in part) (arguing that Koon requires greater deference to district court).

${ }^{8}$ See, e.g., United States v. Rybicki, 96 F.3d 754, 758 (4th Cir. 1996) ("While we review this ultimate departure decision for abuse of discretion, ... if the court's departure is based on a misinterpretation of the Guidelines, our review of that underlying ruling is de novo."); United States $v$. Sablan, 90 F.3d 362, 365 (9th Cir. 1996) ("We do not, however, read Koon as freeing the district court from the general framework of the Guidelines in determining the extent of a departure ...."). See also United States v. Hairston, 96 F.3rd 102 (4th Cir. 1996); United States v. Barber, 93 F.3d 1200, 1204 (4th Cir. 1996); United States $v$. Weinberger, 91 F.3d 642, 644 (4th Cir. 1996); United States v. Charry Cubillos, 91 F.3d 1342 (9th Cir. 1996) (remand of departure, holding that under Koon district court must make inquiry into "structure and theory of Guidelines" and bear in mind Koon's repetition of Commission's expection that departures on grounds not invited by Commission will be "rare"); United States v. Lewis, 90 F.3d 302, 304, 306 (8th Cir. 1996) (citing Koon for proposition that departure relied on error of law and thus was "by definition" an abuse of discretion); United States v. McNeil, 90 F.3d 198 (8th Cir. 1996) (declining to give deference to district court's decision that criminal history calculation was not adequate); United States $v$. Weise, 89 F.3d 501 (8th Cir. 1996); United States v. Taylor, 88 F.3d 938 (11th Cir. 1996).

${ }^{9}$ See 116 S. Ct. at 2046 (asserting four times that sentencing guidelines as interpreted by Supreme Court in Koon itself leave district courts with "much" or a "substantial" portion of their "traditional ... sentencing discretion").

${ }_{10}$ See 18 U.S.C. §3553(b) (judge may depart on own motion only if "there exists an aggravating or mitigating circumstance of a kind, or to a degree, not adequately taken into consideration by the Sentencing Commission. ...").

1 See Koon, 116 S. Ct. at 2052-53 (because Commission 


\section{KATE STITH}

already took factor into account, sentencing court "abused its discretion" by considering that factor).

12 United States v. Barber, 93 F.3d. at 1203.

${ }_{13}$ See cases cited supra notes 7 \& 8.

${ }^{14} 116$ S. Ct. at 2046-47.

15116 S. Ct. at 2047. See also id. at 2048 ("The abuse of discretion standard includes review to determine that the discretion was not guided by erroneous legal conclusions.").

Moreover, in Koon, the Court quoted at length and adopted as its own the multi-pronged inquiry that thenJudge Breyer had set forth in United States v. Rivera, 994 F.2d 942 (1st Cir. 1993). In deciding whether to depart, Judge Breyer had written, the sentencing judge should consider:

(1) What features of this case, potentially, take it outside the guidelines' "heartland" and make of it a special, or unusual, case?

(2) Has the Commission forbidden departures based on those features?

(3) If not, has the Commission encouraged departures based on those features?

(4) If not, has the Commission discouraged departures based on those features?... .

Id. at 949 , quoted at $116 \mathrm{~S}$. Ct. at 2045. All but the first of these are entirely legal, not factual, inquiries. The Supreme Court went on to quote Rivera's further language concerning factors "unmentioned" in the guidelines: "[(5)] The sentencing court should consider the "structure and theory of both relevant individual guidelines and the Guidelines taken as a whole' [to] decide whether [the factor] is sufficient to take the case out of the Guideline's heartand." $116 \mathrm{~S}$. Ct. at 2045, quoting 994 F.2d at 949 . Consideration of "structure and theory" surely betokens a largely legal inquiry.

${ }_{16} 116 \mathrm{~S}$. Ct. at 2052 (factor present to an extent considered by Commission does "not take case out of the heartland").

${ }^{17}$ See United States v. Weinberger, 91 F.3d at 644 ("Given the comprehensive sentencing structure embodied in the guidelines, '[o]nly rarely will we conclude that a factor was not adequately taken into consideration by the Commission,"' (quoting pre-Koon Fourth Circuit cases))

${ }^{18} 116 \mathrm{~S}$. Ct. at 2052 (factor relied on by sentencing court "is not unusual ... so we conclude these consequences were adequately considered by the Commission").

19 See 18 U.S.C. \$ 242.

${ }^{20}$ See 833 F. Supp. 769,787 (C.D. Cal. 1993); see also $2 \mathrm{H} 1.4$.

${ }^{21}$ See 833 F. Supp. at $788-92$.

22 See 34 F.3d 1416 (9th Cir. 1994).

${ }^{23}$ See 116 S. Ct. at 2053 ("The District Court abused its discretion by considering appellants' low likelihood of recividism. The Commission took that factor into account in formulating the criminal history category [I].").

24 See supra text and note 10.

25 As the Supreme Court noted, see 116 S. Ct. at 2052-53, the Commission's Policy Statement on criminal history states that downward departure below Criminal History Category
I for especially low risk of recividism "cannot be appropriate." $\$ 4 \mathrm{~A} 1.3$.

${ }^{26}$ See, e.g., $\$ 5 \mathrm{H} 1.4$ (prohibiting alcohol or drug dependence as reason for downward departure), $\S 5 \mathrm{H} 1.10$ (race, sex, national origin, creed, religion, and socioeconomic status); $\$ 5 \mathrm{H} 1.12$ (lack of guidance as a youth and disadvantaged upbringing).

27116 S. Ct. at 2052.

${ }^{28}$ Id.

${ }^{29} 116$ S. Ct. at 2053 , quoting 833 F. Supp. at $785-86,788$.

$30116 \mathrm{~S}$. Ct. at 2053.

${ }^{31}$ See 833 F. Supp. at 790.

32116 S. Ct. at 2055 (Souter, J., concurring in part and dissenting in part); $116 \mathrm{~S}$. Ct. at 2056 (Breyer, J., concurring in part and dissenting in part).

33116 S. Ct. at 2056 (Breyer, J., concurring in part and dissenting in part).

${ }^{34} \mathrm{Id}$.

35 Sentencing Reform Act of 1987, Pub. L. No. 100-182, § 3, amending 18 U.S.C. \$3553(b). Justice Breyer explained that his conclusions about the civil rights "heartland" were based only "on the [criminal civil rights] statute and the [civil rights] Guideline itself." 116 S. Ct. at 2056 (Breyer, J., concurring in part and dissenting in part).

${ }^{36}$ See also United States $v$. Pullen, 89 F.3d at 371 ("The Supreme Court in Koon emphasized the primacy of the Commission over the courts in determining the proper grounds for departures from the guidelines ranges.").

${ }^{37} 18$ U.S.C. $\$ 3742$ (e) ("Upon review of the record, the court of appeals shall determine whether the sentence ... is outside of the applicable guideine range, and is unreasonable....").

${ }^{38}$ Indeed, the whole concept of the "typical" or "heartland" case would be superfluous. This should not be alarming. After all, the "heartland" is not a concept mentioned in the Sentencing Reform Act or its legislative history, and one can only speculate that it was articulated by the Commission (in the introductory chapter of the Guidelines Manual) after the structure of the guidelines was already determined. That structure does not easily coexist with the idea of a "heartland," at least as that term is used in everyday speech. The guidelines do not map out "heartland" cases. Their detail and comprehensive nature is, rather, responsive to the direction in the Senate Report accompanying the Sentencing Reform Act of 1984, which sought guidelines "sufficiently detailed and refined to reflect every important factor relevant to sentencing for each category of offense and each category of offender, giving appropriate weight to each factor, and deal[ing] with various combinations of factors." S. Rep. No. 225, 98th Cong. 2d Sess., 79 (1984). Superimposing the "heartland" concept on this structure leads to the bizarre result that there are actually as many "heartland" cases as their are permutations within the guidelines themselves-thousands (at least) of different possible combinations of offense categories, adjustments, criminal history score, and the like.

3918 U.S.C. $\S 3553($ b) 